JPdK Volume 3 Nomor 2 Tahun 2021 Halaman 96-101

JURNAL PENDIDIKAN dan KONSELING

Research \& Learning in Primary Education

\title{
Analisis Kesulitan Siswa SMP Kelas VII Dalam Menyelesaikan Persoalan Matematika Pada Soal Cerita Aritmatika Sosial
}

\author{
Ratih Mila Rani ${ }^{1}$, Yoga Adi Pratama ${ }^{2}$, Yuliana Nindi Wardani ${ }^{3}$, Meganis Styorini ${ }^{4}$ \\ Program Studi Pendidikan Matematika \\ Fakultas Keguruan dan Ilmu Pendidikan \\ Universitas PGRI Madiun
}

Email: ratihmilarani14@gmail.com, pratamayogaady@gmail.com,, yuliananindiwardani@gmail.com meganisstyorini7@gmail.com, darmadi7868482@yahoo.com

\begin{abstract}
Abstrak
Penelitian ini bertujuan untuk menganalisis kesalahan siswa dan mngetahui kesulitan siswa dalam mengerjakan soal aritmatika sosial siswa kelas VII. Sampel yang kami gunakan dalam penilitin ini seanyak 5 orang siswa yang berasal dari beberapa SMP di kabutapan Magetan. Teknik yang kami gunakan dalam penelitian ini adalah deskripsi kualitarif yang nantinya akan menjelaskan kesulitan siswa dalam memahami dan menyelesiakan soal aritmatika sosial serta kami juga menyajikan data kesalahan siswa dalam mengerjakan soal. Pengumpulan data yang kami gunakan secara daring dikrenakan tingkat covid di kaupaten Magetan yang meningkat. Dari pengumpulan data tersebut dilakukan beberapa cara yaitu tes dan wawancara. Tes dilakukan dengan memerikan soal yang sudah diuji kevalidannya dan dimodifikasi setelah itu siswa diberikan beberapa pertanyaan terkait konsep aritmatika sosial. Hasil penelitian menunjukan siswa masih kurang terbiasa dalam menuliskan jawaban secara lengkap dan urut serta kesulitan dalam memahami konsep aritmatika sosial, dan ini menyebakan terjadi kesalahan adalam mengerjakan soal yang diberikan. Selain itu pemahaman bahasa juga menjadi poin penting dalam hal ini dikarenakan kurangnya pemahaman bahasa yang digunakan dalam soal mengakibatkan siswa kesulitan memahami konsep.
\end{abstract}

Kata Kunci: Analisis, Aritmatika sosial, Kesulitan Siswa, Pemahaman, Konsep.

\begin{abstract}
This study aims to analyze student errors and find out the difficulties of students in working on social arithmetic problems for class VII students. The sample that we use in this research is 5 students from several junior high schools in Magetan. The technique we use in this study is a qualitative description which will explain the difficulties of students in understanding and solving social arithmetic problems and we also present data on student errors in working on the questions. The data collection that we use online is due to the increasing level of covid in the Magetan district. From the data collection, several methods were carried out, namely tests and interviews. The test is carried out by describing questions that have been tested for validity and modified after that students are given several questions related to the concept of social arithmetic. The results showed that students were still not accustomed to writing complete and sequential answers as well as difficulties in understanding social arithmetic concepts, and this caused errors to occur in working on the questions given. In addition, understanding language is also an important point in this case because the lack of understanding of the language used in the problem results in students having difficulty understanding concepts.
\end{abstract}

Keywords: Analysis, Social Arithmetic, Student Difficulty, Understanding, Concepts. 


\section{PENDAHULUAN}

Matematika adalah ilmu yang berkaitan erat dengan pendidikan terutama dalam perkembangan ilmu pengetahuan dan teknologi. Mengingat pentingnya matematika dalam ilmu pengetahuan, maka dari itu matematika perlu dipahami dan dikuasai oleh semua pelajar maupun masyarakat. Menurut Ruseffendi (Marina \& Suciati, 2019) dalam (Dila \& Zanthy, 2020) mengemukakan bahwa matematika penting sebagai pembentuk sikap, sehingga guru harus mendorong siswa untuk dapat belajar dengan baik.

Pembelajaran merupakan suatu upaya dalam memperbaiki kualitas mutu Pendidikan. Dengan adanya kegiatan pembelajaran yang berjalan dengan baik antara guru dengan muridnya yang melalukan interaksi imbal balik selama proses pembelajaran. Oleh karena itu, siswa diharapkan untuk aktif, kreatif, dan inovatif dalam menanggapi setiap pembelajaran yang diajarkan oleh guru sehingga materi yang disampaikan dapat diterima dengan baik.

Matematika merupakan salah satu mata pelajaran yang dianggap sulit oleh siswa di sekolah, karena untuk mempelajari matematika memerlukan tingkat berpikir tinggi sehingga Sebagian besar siswa mengatakan matematika adalah pelajaran yang sulit serta membosankan. Untuk meningkatkan kemampuan berpikir matematis tingkat tinggi, siswa perlu dibiasakan untuk memecahkan masalah- masalah kontekstual nonrutin (Tusi Fatimah \& Eva Zakiah, 2018). Hal tersebut dapat dilakukan dengan memberikan atau membiasakan siswa untuk menyelesaiakn soal cerita yang sesuai dengan materi yang sedang dipelajarinya. (Aminah \& Ayu Kurniawati, 2018) mengemukakan bahwa soal cerita wujudnya berupa kalimat verbal sehari-hari yang makna dari konsep dan ungkapannya dapat dinyatakan dalam simbol dan relasi matematika.

Dalam penelitiannya (Aminah \& Ayu Kurniawati, 2018) juga menyatakan bahwa memahami makna konsep dan ungkapan dalam soal cerira serta mengubahnya dalam simbol dan relasi matematika, sehingga menjadi model matematika bukanlah hal yang mudah bagi sebagian siswa. (Khasanah \& Sutama, 2015) mengemukakan bahwa ada 3 aspek dalam menyelesaikan soal cerita matematika, yaitu: (1) Aspek bahasa, merupakan kemampuan membaca yang digunakan untuk menafsirkan masalah, sedangkan menalar adalah untuk mengetahui maksud permasalahan yang diberikan. Sejalan dengan pendapat (Laily, 2014) bahwa pelajaran bahasa yang paling mendasar adalah membaca, dengan membaca harus menghasilkan pengertian sehingga pemahaman yang dimiliki siswa bukan kemampuan turun-temurun, tetapi hasil proses belajar mengajar yang dilakukan dengan tekun dan terlatih. (2) Aspek prasyarat, merupakan kemampuan mengubah model matematika dan menentukan strategi untuk menyelesaikan masalah. Erliani (Khasanah \& Sutama, 2015) berpendapat bahwa soal cerita yang diberikan kepada siswa menggunakan bahasa yang sudah dikuasainya maka akan memudahkan siswa dalam mengubah ke model matematika. Siswa diharapkan mampu memecahkan masalah dan dapat menyelesaikan jawaban dengan menggunakan aturan-aturan rumus yang telah dipelajari Bersama guru. (3) Aspek terapan, merupakan kemampuan siswa melakukan proses perhitungan yang tepat dengan menggunakan rumus.

Menurut pendapat (Khasanah \& Sutama, 2015) menyimpulkan bahwa kesulitan siswa dalam menyelesaikan soal matematika yaitu: (1) kesulitan aspek bahasa, misalnya siswa salah menafsirkan soal, memahami soal, dan mengidentifikasi maksud soal, serta menceritakan kembali soal dengan bahasa sendiri; (2) kesulitan aspek prasyarat, misalnya siswa tidak menuliskan apa yang diketahui dan ditanyakan, mengubah ke bentuk model matematika, dan tidak menguasai konsep sehingga sulit menentukan rumus; (3) kesulitan aspek terapan, misalnya tidak bisa menggunakan rumus dengan tepat, hal ini berakibat kurangnya ketelitian siswa.

Aritmatika sosial adalah salah satu materi matematika yang penting untuk dipelajari oleh siswa karena berkaitan dengan kehidupan sehari - hari mengenai harga penjualan, harga pembelian, keuntungan, kerugian, bunga, diskon, pajak, bruto, tara, dan neto seperti menurut (Muslika, 2014) menyatakan matematika termasuk Aritmatika Sosial didalamnya merupakan suatu mata pelajaran yang sering digunakan dalam kehidupan sehari-hari, di tempat kerja ataupun untuk mempelajari mata pelajaran yang lainnya, keterampilan matematika sosial sangat dibutuhkan di rumah ataupun di tempat kerja. Sehingga dapat menyelesaikan masalah tersebut di masa yang akan datang. Meskipun materi aritmatika sosial penting untuk dipelajari, tetapi masih ada siswa yang mengalami kesulitan dalam menyelesaikan masalah tersebut, sehingga penelitian ini penting untuk dilakukan.

Menurut hasil penelitian yang dilakukan oleh (Evijayanti \& Khotimah, 2016) di Surakarta menyimpulkan bahwa jenis kesulitan yang dialami siswa dalam menyelesaikan soal cerita aritmatika sosial digolongkan menjadi tiga, yaitu: (1) kesulitan dalam memahami soal; (2) kesulitan dalam mentransformasikan soal; dan (3) kesulitan dalam proses penyelesaian. Penyebabnya adalah siswa malas membaca soal yang panjang, kesulitan dalam menafsirkan soal, minat belajar siswa kurang, siswa cenderung lebih menghafal daripada memahami konsep, siswa kurang latihan soal-soal, masih salah dalam melakukan perhitungan, motivasi belajar siswa rendah, pada saat pembelajaran di kelas kurang kondusif dan metode pembelajaran yang digunakan oleh guru adalah metode ceramah.

Berdasarkan penelitian yang sudah dilakukan 
tersebut dan pembahasannya yang berbeda, oleh karena itu kegiatan penelitian ini dilakukan pada siswa SMP kelas VII di kabupaten Magetan dengan penelitian yang sejenis, tetapi peneliti akan menggunakan pembahasan yang berbeda yaitu berdasarkan aspek bahasa, aspek prasyarat, dan aspek terapan. Penilitian ini diharapkan dapat bermanfaat bagi guru serta pelajar untuk menemukan cara lebih mudah dalam mempelajari ataupun menyelesaiakan soal cerita yang berkaitan dengan materi aritmatika sosial.

\section{METODOLOGI PENELITIAN}

Subjek penelitian ini adalah siswa kelas VII dari beberapa sekolah yang ada di kaupaten Magetan yang terdiri dari 5 orang siswa. Metode penelitian yang kai gunakan adalah metode deskripsi kualitatif yang bertujuan untuk mengetahui kesulitan siswa dalam mengerjakan soal aritmatika. Data yang sudah kami kumpulkan berupa analisis kesalahan siswa dalam menyelesaikan soal dengan instrumen soal yang kami ambil dan modifikasi dari (Wulandari \& Riajanto, 2020) dan sudah terbukti kevalidannya. Teknik analisis yang kami gunakan antara lain: (1) pengumpulan data, dilakukan dengan tujuan agar kami seagai peneliti dapat memerikan kecocokan penelitian kami dengan sujek penelitian. (2) reduksi data, ditujukan untuk pengelompokkan data berdasarkan tingkat keukaran soal. (3) penyajian data, dilakuka guna memudahkan dalam implementasi dan juga penarikan keseimpulan.

(4) penarikan kesimpulan, dilakukan saat semua instrumen penelitian telah dilaksanakan dan diperoleh kesimpulan sesuai dengan permasalahan dan tujuan penelitian.

\section{HASIL PENELITIAN DAN PEMBAHASAN}

Setelah dilakukannya penelitian terhadap siswa SMP kelas VII yang berjumlah 5 orang siswa, maka diperoleh hasil penellitian berupa kesalahan- kesalahan siswa yang berakibat siswa mengalami kesulitan pada saat menyelesaikan soal pada materi aritmatika sosial terutapa pada soal cerita. Adapun beberapa kesalahan siswa dalam menyelesaikan soal adalah, siswa belum dapat menafsirkan soal dengan tepat, siswa belum mampu memahami dan menafsirkan soal, siswa belum mampu menceritakan kembali apa yang dimaksud dalam soal kedalam bahasanya sendiri, siswa sering kali lupa untuk menuliskan apa yang diketahui dan ditanyakan pada soal, siswa terkadang belum tepat dalam mengubah soal kedalam model matematika, siswa kurang memahami konsep yang berkaitan, siswa juga belum fasih dalam menggunakan rumus dan kurang teliti, selain itu siswa seringkali mengabaikan dan tidak menuliskan kesimpulan terhadap keterkaitan hasil yang telah dikerjakan terhadap soal yang diterima. Dari beberapa kesalahan yang telah diketahui, maka perlu dilakukan persepsi terhadap tiga aspek, antara lain:

\section{Aspek Bahasa}

Aspek Bahasa merupakan suatu kemampuan membaca yang digunakan untuk menafsirkan suatu soal agar siswa dapat memahami dan menerjemahkan suatu persoalan dalam soal, dan menalar adalah untuk mengetahui maksud permasalahan dalam soal yang telah diberikan. Dengan kemampuan aspek bahasa maka akan mampu menceritakan kembali apa yang dimaksudkandidalam soal kedalam bahasanya sendiri.

\section{Aspek Prasyarat}

Aspek Prasyarat merupakan kemampuan untuk memodifikasi soal kedalam model matematika, sehingga mampu menentukan konsep dan rumus untuk strategi penyelesaian dalam suatu masalah.

\section{Aspek Terapan}

Aspek Terapan merupakan kemampuan untuk melakukan atau menyelesaikan perhitungan degan tepat dalam menerapkan suatu rumus, sehingga mampu untuk menarik kesimpulan dari hasil yang diperoleh.

Hasil tes kesulitan siswa dalam penelitian ini dapat dilihat pada tabel berikut :

Table 1.Data Siswa yang Mengalami Kesulitan Menyelesaian Soal

\begin{tabular}{ccc}
\hline Aspek & $\begin{array}{c}\text { Jumlah } \\
\text { Siswa }\end{array}$ & Presentase \\
\cline { 1 - 1 } Aspek Bahasa & 5 Siswa & $80 \%$ \\
\cline { 1 - 1 } Aspek Prasyarat & 2 Siswa & $40 \%$ \\
\hline Aspek Terapan & 4 Siswa & $80 \%$ \\
\hline
\end{tabular}

Berdasarkan Tabel 1 telah menunjukkan bahwa: (1) presentase siswa yang mengalami kesulitan dalam aspek Bahasa sebesar $80 \%$, kesulitan ini meliputi siswa sulit memahami soal sehingga siswa tidak dapat mengidentifikasi maksut permasalahan pada soal dan kurang mampu dalam menceritakan dengan bahasanya sendiri. (2) dan presentase siswa yang mengalami kesulitan dalalm aspek prasyarat sebesar 40\%, disini ada beberapa siswa yang masih mengabaikan apa yang diketahui dan ditanyakan sehingga siswa menulis langsung pada jawaban, selain itu dalam menggunakan model matematika dan menentukan rumus kadang siswa masih mengalami kebingungan. (3) selain presentase dari aspek mahasa yang tinggi, disini kesulitan siswa dalam aspek terapan juga memiliki presentase yang cukup tinggi yaitu $80 \%$, dimana kesulitan ini meliputi, siswa yang kurang teliti dalam menggunakan rumus dan pada saat menghitung, serta siswa cenderung instan dan kurang mampu membuat kesimpulan.

Setelah memperoleh hasil tes yang telah diberikan, maka dapat dilihat bahwa siswa masih 
mengalami kesulitan dalam menyelesaikan suatu permasalahan pada soal Aritmatika Sosial. Dilihat dari semua aspek diketahui bahwa siswa paling banyak mengalami kesulitan pada aspek bahasa, yaitu dimana siswa kurang mampu memahami dan mengidentifikasi soal sehingga siswa kurang mampu dalam menceritakan kembali maksut soal tersebut kedalam bahasanya sendiri. Untuk mengetahui letak kesulitan-kesulitan yang dialami siswa dalam menyelesaikan soal tersebut dapat dilihat dari beberapa kesalahan siswa dalam menuliskan jawaban serta langkah-langkah yang digunakan pada soal tes adalah seperti berikut :

\section{a. Analisis kesalahan pada soal nomor 1}

Soal : Jika harga $1 \mathrm{~kg}$ gula Rp.5.500 dan harga $1 \mathrm{~kg}$ tepung terigu Rp.4.700. Maka buatlah persamaannya untuk harga $5 \mathrm{~kg}$ gula dan $3 \mathrm{~kg}$ tepung terigu dan tentukan berapa harganya.

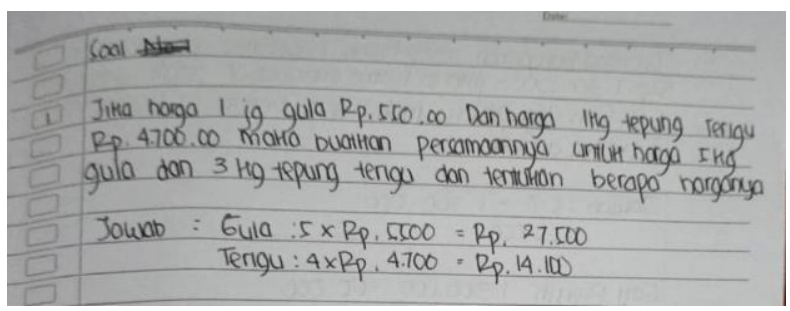

Gambar 1. Hasil Penyelesaian Siswa Pada Soal No 1

Pada Gambar 1 menunjukkan bahwa siswa mengalami kesulitan dalam aspek bahasa, dimana pada penyelesaian ini siswa kesulitan dalam menafsirkan suatu permasalahan yang diperintahkan pada soal, seharusnya siswa persamaan dari dulu seperti yang ada pada soal, namun disini siswa langsung menghitung hasil nya tanpa membuat persamaannya sehingga jawaban tidak lengkap. Dan siswa juga mengalami kesulitan dalam aspek prasyarat, karena pada penyelesaian ini siswa tidak menuliskan apa yang diketahui dan ditanyakan, bisa saja siswa tersebut lupa atau mungkin karena tidak teriasa, siswa juga masih kesusahan dalam mengubah soal kedalam model matematika. Selain dua aspek tadi, siswa juga mengalami kesulitan dalam aspek lain yaitu aspek terapan, siswa kurang teliti dalam mengerjakan soal sehingga penyelesaian yang diminta kurang tepat, seharusnya dalam jawaban itu tertera persamaannya sehingga lebih mudah ketika menjawabnya, missal $5 \mathrm{x}+3 \mathrm{y}$ sehingga diperoleh hasil $5 x+3 y=5(\operatorname{Rp} .5 .500)+3(\operatorname{Rp} .4 .700)=$ Rp.27.500 + Rp.14.100 = Rp. 41.600. selain itu siswa juga tidak mampu menarik kesimpulan dari hasil yang dikerjakan.

\section{b. Analisis kesalahan pada soal nomor 2}

Soal : Sebuah barang dibeli dengan harga Rp.75.000 dan dijual dengan laba 25\%. Tentukan harga jual barang tersebut !

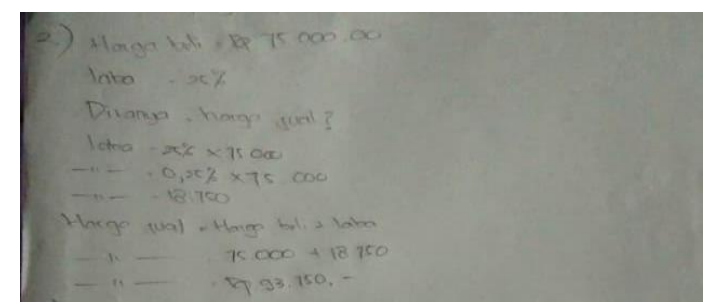

Gambar 2. Hasil Penyelesaian Siswa Pada Soal No 2

Pada Gambar 2 menunjukkan bahwa dalam aspek bahasa siswa tidak mengalami kesulitan karena siswa sudah mampu memahami permasalahan pada soal dan dapat menceritakan dengan bahasanya sendiri, pada aspek prasyarat pun juga sama, siswa sudah tidak mengalami kesulitan perihal menuliskan hal-hal yang diketahui dan ditanyakan serta mampu menentukan rumus yang sesuai. Namun siswa masih mengalami kesulitan dalam aspek terapan, dimana siswa belum dapat menarik kesimpulan dari hasil jawaban yang telah diselesaikan. Missal, jadi harga jual barang tersebut adalah Rp.93.750.

\section{c. Analisis kesalahan pada soal nomor 3}

Soal : Seorang siswa menabung di Bank sebesar Rp.100.000 dengan bunga 1,2\% perbulan. Setelah 7 bulan tabungan itu diambil.

a. Buatlah tabelnya

b. Hitunglah jumlah tabungan selama 7 bulan

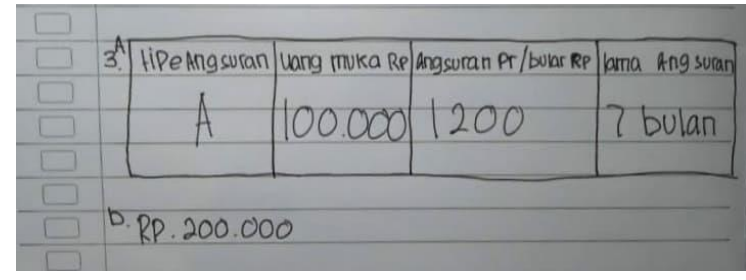

Gambar 3. Hasil Penyelesaian Siswa Pada Soal No 3

Pada Gambar 3 menunjukkan bahwa siswa mengalami kesulitan dalam aspek bahasa, aspek prasyarat, dan aspek terapan. Dimana dalam aspek Bahasa siswa belum mampu dalam mengidentifikasi soal kedalam bahasanya sendiri, pada aspek prasyarat siswa belum mampu menuliskan apa yang diketahui dan ditanyakan sehingga siswa tidak bisa menentukan rumus yang tepat. Pada aspek terapan pun siswa juga masih mengalami kesulitan, karena siswa belum mampu menggunakan rumus sehingga dalam proses pengerjaannya siswa tersebut menduga-duga jawaban sehingga jawaban tidak tepat.

\section{d. Analisis kesalahan pada soal nomor 4}

Soal : Seorang karyawan setiap bulan menerima gaji sebesar Rp. 1.300.000. Jika ia harus membayar pajak sebesar 5\% dari gaji pokok, apakah benar gaji bersih yang diterima karyawan itu Rp. 1.235.000 ? 


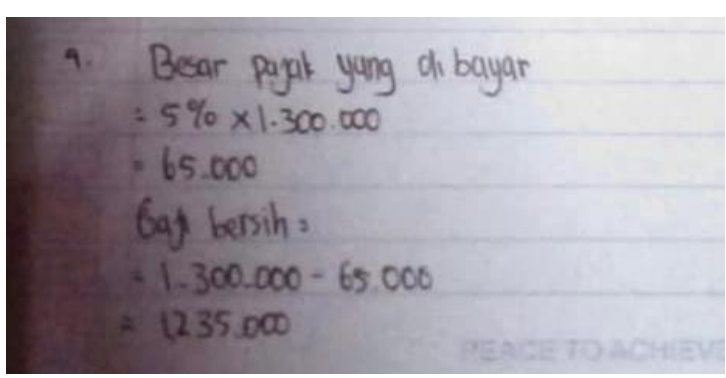

Gambar 4.Hasil Penyelesaian Siswa Pada Soal No 4

Pada Gambar 4 menunjukkan bahwa siswa mengalami kesulitan dalam aspek bahasa, karena dalam soal yang diberikan seharusnya siswa memperoleh hasil akhir berupa jawaban dengan menuliskan "benar" atau "salah" namun siswa hanya menghitungnya dan belum menjawab secara lengkap. Pada aspek prasyarat siswa kesulitan dalam menuliskan diketahui dan ditanyakan, namun siswa sudah mampu menentukan rumus. Pada aspek terapan siswa juga masih mengalami kesulitan pada menarik kesimpulan sehingga jawaban yang dihasilkan tidak lengkap. Misal, jadi gaji bersih yang diterima karyawan itu benar sebesar Rp.1.235.000.

\section{e. Analisis kesalahan pada soal nomor 5}

Soal : Pak Budi membeli sebuah radio dengan harga sesudah di diskon 15\% adalah Rp. 765.000 maka berapa harga radio ketika belum di diskon ?

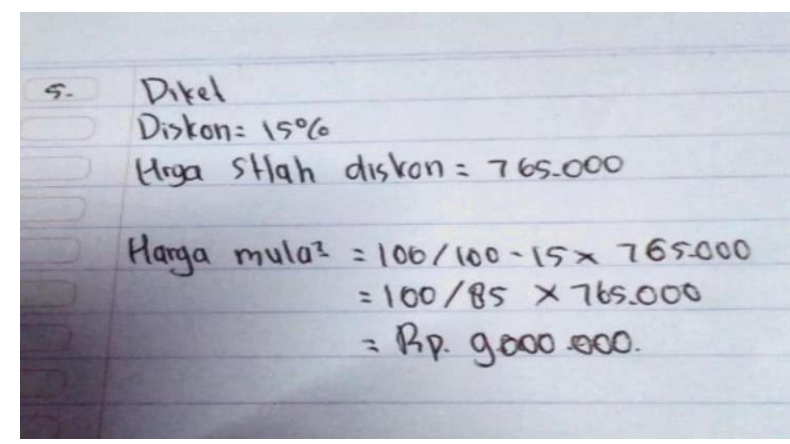

Gambar 5.Hasil Penyelesaian Siswa Pada Soal No 5

Pada Gambar 5 menyatakan bahwa dalam aspek bahasa siswa tidak terlalu mengalami kesulitan karena siswa sudah mampu memahami maksut yang ditanyakan pada soal, namun siswa masih belum mampu menceritakan keadaan soal dalam bahasanya sendiri. Pada aspek prasyarat siswa tidak mengalami kesulitan, karena sudah mampu menuliskan mana yang diketahui dan ditanyakan pada soal,. Kemudian pada aspek terapan siswa masih mengalami kesulitan karena siswa kurang teliti dalam menghitung hasil penyelesaian sehingga jawaban salah.

\section{SIMPULAN}

ddilakukan

Berdasakan hasil penelitian yang

oleh tim peneliti diadaptkan kesulitan-

kesulitan dianalisis menjadi tiga aspek, yaitu: (1) siswa masih 
kesulitan memahami bahasa yang digunakan dalam soal aritmatika sosial. Presentase dalm aspek ini mencapai 80

$\%$ dimana seluruh siswa yang menjadi sampel penelitian kami keseluruihannya masih sangat keslutian dalam memahami bahasa yang digunakan. (2) di aspek prsyarat ini mencapai $40 \%$ dimana aspek ini menunjukkan modifikasi soal kedalam model matematika. Siswa masih sedikit kesulitamn dalam memahami konsep dan rumus dalam menyelesaiakan soal aritmatika sosial. (3) Aspek terapan, dalam penelitian kami aspek ini mencapai $80 \%$ dimana artinya siswa tidak dapat menyelesaikan perhitungan dengan tepat sesuai rumus yang sudah dierikan. Ini sangat berkaitan dengan pemahaman bahasa dan juga konsep dari aritmatika sosial sendiri.

Aspek diatas menunjukkan penyebab dari kesulitan siswa dalam menyelesaikan soal aritmatika sosial dikarenakan kurangnya pemahaman terhadap konsep dan kurangnya membiasakan menulis jawaban dengan lengkap dan urut. Kekurangan meembiasaan menulis jawaban dengan urut dan konsep yang belum dikuasi oleh siswa akan memuat siswa kebingungan dsalam mngerjakan soal yang diberikan. Rumus yang hanya mereka hafalkan tidak membantu siswa dalam mngerjakan soal yang diberikan. Pastinya ini sangat mengganggu dan perlu adanya evaluasi rutin anatara pendidik dan peserta didik.

\section{DAFTAR PUSTAKA}

Aminah, A., \& Ayu Kurniawati, K. R. (2018). Analisis Kesulitan Siswa Dalam Menyelesaikan Soal Cerita Matematika Topik Pecahan Ditinjau Dari Gender. JTAM | Jurnal Teori Dan Aplikasi Matematika, $2(2)$, 118. https://doi.org/10.31764/jtam.v2i2.713

Dila, O. R., \& Zanthy, L. S. (2020). Identifikasi Kesulitan Siswa Dalam Menyelesaikan Soal Aritmatika Sosial. Teorema: Teori Dan Riset Matematika, $5(1), \quad 17$. https://doi.org/10.25157/teorema.v5i1.3036
Evijayanti, W., \& Khotimah, R. P. (2016). Analisis Kesulitan Siswa Kelas VII SMP Negeri 3 Kartasura Dalam Menyelesaikan Soal Cerita Aritmatika Sosial. http://eprints.ums.ac.id/id/eprint/44857

Khasanah, U. \& Sutama. (2015). Kesulitan

Menyelesaikan Soal Cerita Matematika pada Siswa SMP. Prosiding Seminar Nasional Pendidikan Matematika, 79-89. http://hdl.handle.net/11617/6131

Laily, I. F. (2014). Hubungan Kemampuan Membaca Pemahaman Dengan Kemampuan Memahami Soal Cerita Matematika Sekolah Dasar. Eduma: Mathematics Education Learning and Teaching, 3(1). https://doi.org/10.24235/eduma.v3i1.8

Muslika. (2014). Meningkatkan Hasil Belajar Siswa Kelas Vii C Smp Negeri 1 Mumbulsari Jember Pada Materi Aritmatika Sosial Dengan Model React (Relating, Experiencing, Applying, Cooperating, Transferring) Tahun 2012/2013. Kadikma, 5(1), 175-186.

Tusi Fatimah, A., \& Eva Zakiah, N. (2018). Kelancaran Prosedural Matematis Dalam Pemecahan Masalah Konteks Pemasaran. $M A$ $\begin{array}{lllllll}T & H & L & I & N & E: \text { Jurnal Matematika Dan }\end{array}$ Pendidikan Matematika, 3(2), 141-150. 141150. https://doi.org/10.31943/mathline.v3i2.92

Wulandari, L., \& Riajanto, M. L. E. J. (2020). Analisis Kesulitan Siswa SMP dalam Menyelesaikan Soal Materi Teorema Pythagoras. Jurnal Riset Pendidikan Dan Inovasi Pembelajaran Matematika (JRPIPM), $3(2)$, 61.

https://doi.org/10.26740/jrpipm.v3n2.p61-67 